\title{
The use of wild medicinal raw materials in food production
}

\author{
Alla V. Volkova*, Vladimir N. Sysoev, and Andrey N. Makushin \\ Samara State Agrarian University, Kinel 446442, Samara region, Russia
}

\begin{abstract}
Research on the composition of new types of food products, including those enriched with physiologically functional ingredients, is relevant and promising, since it allows us to organize public nutrition on a scientific and hygienic basis. The aim is experimental justification of the use of wild medicinal raw materials in food production. The methodological basis is a systematic analysis of the technology for the production of bakery products, non-alcoholic carbonated drinks and poultry sausages enriched with wild medicinal raw materials. In accordance with the chosen method, the problem of choosing and justifying the use of wild-growing phyto-enrichment agents of different species has been solved. It has been established that the introduction of phyto-enrichment agents has a positive effect on maturation processes of the dough. The use of wild medicinal raw materials is more justified in the form of herbal infusions. In the production of non-alcoholic carbonated drinks, drinks containing hawthorn, echinacea grass, linden flowers, lingonberry leaves, rose hips and thyme herbs have the most harmonious taste. In the production of sausages, wild-growing medicinal raw materials can be used as water-alcohol infusions and crushed raw materials. A water-alcohol infusion of fireweed narrow-leaved has the greatest inhibitory effect on the development of bacteria.
\end{abstract}

\section{Introduction}

Human health depends on a diet. Optimum nutrition is a key factor determining an ability to work, life expectancy and preservation of the nation's gene pool. Moreover, the determination of appropriate dietary strategies for the prevention of chronic degenerative diseases, cancer, diabetes and cardiovascular diseases is a complex urgent problem [1-5]. Currently, in all developed countries issues of healthy nutrition are a part of the policy. Including the "Fundamentals of the national policy in the field of healthy nutrition of the population of the Russian Federation until 2020", the priority task is to increase the production of massconsumed nutritious foods

The term "functional nutrition" means proper food consumption and the use of new generation foods characterized by predetermined properties and having a mobilizing effect on the body's own mechanisms and reserves that regulate its vital activity, and improve the performance of its specific systems, organs or their functions [6].

One of the urgent areas of modern research is the study of the use of wild-growing medicinal raw materials in the production of traditional food products. Scientists are studying the composition of potential phytopathic agents and their functional properties [7-11]. The research results prove that the phytochemicals contained in wild medicinal raw materials are bioactive plant compounds that can be used as antimicrobial, antibacterial agents. They prevent cancer, cardiovascular and inflammatory diseases [12]. The antimicrobial activity of herbs containing essential oils in the range of 0.05-0.1\% was found for Salmonella typhimurium, Escherichia coli, Listeria monocytogenes, Bacillus cereus and Staphylococcus aureus and Penicillium ochrochloron [13, 14]. At the same time, the possible dose of additional wild-growing medicinal raw materials is often limited by sensory restrictions [15], which does makes it impossible to use them in high concentrations for suppressing pathogenic microorganisms in food and prolonging the shelf life.

The use of natural plant materials in food production is crucial.

The purpose of this study is an experimental justification for the use of wild medicinal plant materials in the production of functional foods. The research objectives are to determine the effect of wild-growing medicinal plant materials on the organoleptic and physico-chemical quality indicators of bread made from wheat flour, soft drinks and sausages; to optimize the recipe components of premium wheat flour bread, soft drinks and sausages containing wild-growing medicinal raw materials.

The objects of research were bakery products, nonalcoholic carbonated drinks and sausages containing promising wild-growing phyto-enrichment agents, production technologies and recipes. The subject is the influence of wild-growing medicinal raw materials on the consumer properties of finished bakery, sausage products and soft drinks.

The development of recipes of these products using promising types of wild-growing medicinal raw materials is of great theoretical and practical interest. It

* Corresponding author: avvolkova76@ rambler.ru 
creates prerequisites for expanding the assortment, improving quality, increasing the nutritional and biological value of the finished product.

\section{Materials and methods}

When planning the experiments, the types of raw materials growing in the Middle Volga region and having a strengthening and immuno-stimulating effect were selected as additional wild-growing medicinal raw materials.

In experiments with bread, the unpaired method of preparing dough was used. During the research, premium quality wheat flour was used. Bread was baked by the test laboratory baking method and assessed by the quality indicators.

As additional raw materials, wild medicinal herbs were used. We studied the effect of wild medicinal herbs on the consumer properties of bread:

- dry powder in the amount of 1-5\%. Dry chopped chicory and thyme were used;

- water infusion in the amount of $20 \%$ of water required for kneading the dough. Water infusions of flax, yarrow, fireweed narrow-leaved and linden flowers were used.

When producing non-alcoholic carbonated drinks, water extracts from dried wild medicinal plant materials were used as a basis: fruits of hawthorn, leaves of lingonberry, linden flowers, leaves of coltsfoot, licorice powder, leaves and chicory root, creeping thyme, sage leaves, ground rose hips, echinacea grass. Test batches of soft carbonated drinks were produced using classical technologies, followed by quality assessment according to the generally accepted methods.

When producing sausages, we used:

- water-alcohol infusions of herbs infused using a 70 $\%$ water-alcohol mixture: narrow-leaved fireweed; Hypericum perforatum; yarrow; lemongrass; agrimonia. Model versions of sausages were developed using wateralcohol infusions of herbs in the amount of $1.0 \mathrm{~kg}$ per $100.0 \mathrm{~kg}$ of unsalted raw materials.

- finely chopped thistle. Model versions sausages were produced using thistle in the amount of 1.0, 3.0, 6.0 and $9.0 \%$ per $100.0 \mathrm{~kg}$ of unsalted raw materials.

The main meat component was poultry (chicken) obtained by manual boning. The production of sausages was carried out on the equipment of the training and production laboratory in conditions close to the real ones. Quality assessment was carried out according to the generally accepted methods.

All the experiments described were performed 3-4times, and analytical determinations were made thrice. The tables show data of the typical experiments. Only those results that were reproducible in each experiment are discussed. The deviations did not exceed $1-3 \%$.

\section{Results}

Before conducting laboratory tests, we investigated the quality indicators of the wheat flour which characterize its suitability for baking. Baking wheat flour had a taste characteristic of this product, a white color with a cream tint, and a smell characteristic of wheat baking flour (Table 1). In the experiment, wheat flour was used.

Table 1. Organoleptic and physicochemical indicators of bakery flour quality taken for research purposes

\begin{tabular}{|c|c|c|}
\hline \multirow[t]{2}{*}{ Indicator } & \multicolumn{2}{|c|}{ Value } \\
\hline & $\begin{array}{c}\text { Russian standard's } \\
\text { requirements }\end{array}$ & Actual value \\
\hline Flavor & $\begin{array}{c}\text { Peculiar to wheat flour, } \\
\text { without extraneous } \\
\text { flavors, not sour, not } \\
\text { bitter }\end{array}$ & $\begin{array}{l}\text { Peculiar to wheat } \\
\text { flour, without } \\
\text { extraneous } \\
\text { flavors, not sour, } \\
\text { not bitter }\end{array}$ \\
\hline Color & White or creamy white & Creamy white \\
\hline Odor & $\begin{array}{l}\text { Peculiar to wheat flour, } \\
\text { without extraneous } \\
\text { flavors, not musty, not } \\
\text { mouldy }\end{array}$ & $\begin{array}{l}\text { Peculiar to wheat } \\
\text { flour, without } \\
\text { extraneous } \\
\text { flavors } \\
\end{array}$ \\
\hline $\begin{array}{c}\text { Mass share of } \\
\text { moisture, } \%\end{array}$ & Not more than 15.0 & 11.3 \\
\hline $\begin{array}{c}\text { Mineral } \\
\text { impurities }\end{array}$ & $\begin{array}{l}\text { When chewing flour, } \\
\text { you should not feel a } \\
\text { crunch }\end{array}$ & $\begin{array}{l}\text { When chewing } \\
\text { flour, a crunch } \\
\text { has not been felt }\end{array}$ \\
\hline Pest infestation & Not allowed & Not found \\
\hline Pest pollution & Not allowed & Not found \\
\hline $\begin{array}{c}\text { Mass fraction } \\
\text { of ash, } \%\end{array}$ & Not more than 0.55 & 0.50 \\
\hline $\begin{array}{c}\text { Mass fraction } \\
\text { of crude gluten, } \\
\%\end{array}$ & Not less than 28.0 & 34.5 \\
\hline $\begin{array}{l}\text { Gluten quality, } \\
\text { units IDK }\end{array}$ & - & 82.0 \\
\hline $\begin{array}{c}\text { Gluten Quality } \\
\text { Group }\end{array}$ & Not lower than II & II \\
\hline Fall number, c & Not less than 185 & 346 \\
\hline $\begin{array}{l}\text { Acidity, } \\
\text { degrees }\end{array}$ & - & 2.2 \\
\hline
\end{tabular}

According to the organoleptic and physico-chemical parameters, wheat flour met the requirements.

The dried medicinal herbs used had similar values for moisture and extractiveness, and were in the ranges of 9.2...9.7 and $24.8 \ldots 26.2 \%$, respectively.

The results of organoleptic assessment of bread with wild-growing medicinal raw materials showed that chicory and thyme powder do not deteriorate quality (Table 2).

In particular, in bread made from chicory root flour, the crust remains convex, with a flat surface, the crumb is characterized by uniform porosity and elasticity, although it acquires a grayish tint, the bread has a characteristic taste.

An increase in the mass fraction of chicory decreases crust convexity, its color becomes fair, the surface becomes uneven, with cracks, crumb porosity is uneven as well. The $5 \%$ chicory flour makes the crumb grey, the bread taste is lenten, bitter.

When adding thyme ( $1 \%$ of the flour weight), the crust state becomes worse, it is uneven, with cracks, the crumb is porous and uneven. 
Table 2. Organoleptic and physico-chemical quality indicators of bread from wheat flour of the highest grade with the use of chicory root powder and thyme

\begin{tabular}{|c|c|c|c|c|c|}
\hline Option & 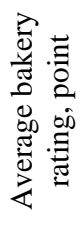 & 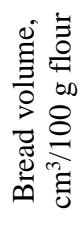 & 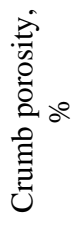 & 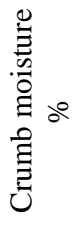 & 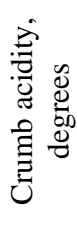 \\
\hline Control & 5.0 & 290 & 81.0 & 41.4 & 2.0 \\
\hline $\begin{array}{l}\text { Bread with } 1 \% \\
\text { chicory root } \\
\text { powder }\end{array}$ & 4.9 & 240 & 73.0 & 42.5 & 2.8 \\
\hline $\begin{array}{c}\text { Bread with } 2 \% \\
\text { chicory root } \\
\text { powder }\end{array}$ & 4.7 & 240 & 73.5 & 42.5 & 2.9 \\
\hline $\begin{array}{l}\text { Bread with } 3 \% \\
\text { chicory root } \\
\text { powder }\end{array}$ & 4.7 & 250 & 75.0 & 42.7 & 3.0 \\
\hline $\begin{array}{l}\text { Bread with } 4 \% \\
\text { chicory root } \\
\text { powder }\end{array}$ & 3.3 & 235 & 74.5 & 42.9 & 3.0 \\
\hline $\begin{array}{c}\text { Bread with } 5 \% \\
\text { chicory root } \\
\text { powder }\end{array}$ & 2.7 & 235 & 72.5 & 43.0 & 3.1 \\
\hline $\begin{array}{l}\text { Bread with } 1 \% \\
\text { Thyme Powder }\end{array}$ & 4.7 & 240 & 73.3 & 42.5 & 2.8 \\
\hline $\begin{array}{l}\text { Bread with } 2 \% \\
\text { Thyme Powder }\end{array}$ & 4.4 & 240 & 74.0 & 42.6 & 2.8 \\
\hline $\begin{array}{l}\text { Bread with } 3 \% \\
\text { Thyme Powder }\end{array}$ & 3.4 & 250 & 73.0 & 42.7 & 2.9 \\
\hline $\begin{array}{l}\text { Bread with } 4 \% \\
\text { Thyme Powder }\end{array}$ & 2.7 & 225 & 72.0 & 42.9 & 3.0 \\
\hline $\begin{array}{l}\text { Bread with } 5 \% \\
\text { Thyme Powder }\end{array}$ & 2.5 & 220 & 70.5 & 42.9 & 3.1 \\
\hline $\begin{array}{c}\text { Russian } \\
\text { standard } \\
\text { requirements }\end{array}$ & 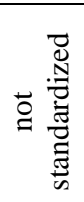 & 宽 & 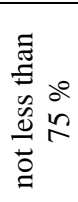 & 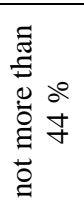 & 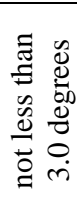 \\
\hline
\end{tabular}

The crumb was elastic. The taste was unsusual but pleasant.

Herb infusions had a slightly different effect on the quality indicators of bread. The absence of particles and fibers of herbs led to the absence of dark inclusions in the dough and contributed to the preservation of its rheological properties. Extractives were distributed evenly, increasing the nutritional value of the product. The shape and convexity of the crust did not differ from the control one. The crust was light brown and brown. The surface of the crust was smooth.

In terms of crumb color, the bread options had differences due to the color of the feedstock. A more yellow color of the crumb was observed in bread with infusions of linden and linden flowers, a grayish tint was recorded in the crumb with the use of narrow-leaved fireweed.

Porosity of the crumb corresponded to the standard, but when using infusions made from St. John's wort, yarrow and fireweed narrow-leaved, it was uneven. At the same time, the bread crumb was elastic in all the options. The use of aqueous extracts of yarrow and linden flowers gave the crumb greater elasticity.

The taste corresponded to the taste inherent in this product.

Table 3. Physico-chemical characteristics of bread made from premium wheat flour with the use of wild herbs

\begin{tabular}{|c|c|c|c|c|}
\hline \multirow{2}{*}{$\begin{array}{c}\text { Wheat } \\
\text { bread with } \\
\text { the use of } \\
\text { herbal } \\
\text { infusion }\end{array}$} & \multirow{2}{*}{$\begin{array}{c}\text { Average } \\
\text { bakery } \\
\text { rating, point }\end{array}$} & \multicolumn{3}{|c|}{ Physico-chemical characteristics } \\
\hline & & $\begin{array}{l}\text { Crumb } \\
\text { acidity, } \\
\text { degrees }\end{array}$ & $\begin{array}{c}\text { Crumb } \\
\text { moisture } \\
\%\end{array}$ & $\begin{array}{c}\text { Crumb } \\
\text { porosity, } \\
\%\end{array}$ \\
\hline Control & 4.54 & 1.8 & 39.8 & 73.0 \\
\hline $\begin{array}{l}\text { Hypericum } \\
\text { perforatum }\end{array}$ & 4.56 & 1.6 & 40.0 & 74.0 \\
\hline Agrimony & 4.71 & 1.6 & 40.4 & 75.1 \\
\hline Yarrow & 4.54 & 1.6 & 40.4 & 76.2 \\
\hline $\begin{array}{c}\text { Fireweed } \\
\text { angustifolia }\end{array}$ & 4.64 & 1.6 & 41.0 & 73.2 \\
\hline $\begin{array}{l}\text { Linden } \\
\text { flowers }\end{array}$ & 4.71 & 1.8 & 40.8 & 75.3 \\
\hline $\begin{array}{c}\text { Standard } \\
\text { requirement } \\
\mathrm{s}\end{array}$ & $\begin{array}{c}\text { not } \\
\text { standardized }\end{array}$ & $\begin{array}{c}\text { not } \\
\text { more } \\
\text { than } \\
3.0\end{array}$ & $\begin{array}{c}\text { not } \\
\text { more } \\
\text { than } \\
44.0\end{array}$ & $\begin{array}{c}\text { not less } \\
\text { than } \\
72.0\end{array}$ \\
\hline
\end{tabular}

It was noted that crumb acidity in options with the use of additional raw materials, with the exception of linden flowers, decreased slightly compared to the control option. This is due to the phytoncide properties of medicinal raw materials manifested in inhibition of the yeast development.

When determining the porosity of the crumb, a trend to its increase was revealed when introducing different types of infusions made from wild medicinal herbs. So, its smallest value was obtained in the "control" option $(73.0 \%)$. The maximum value of crumb porosity was observed in bread crumb when using a yarrow infusion $(76.2 \%)$. Intermediate crumb porosity values of 74.0...75.3 \% were obtained in bread made with infusions of turnip, St. John's wort and linden flowers.

The use of wild-growing plant materials in bread and drinks is relevant.

The results of our marketing research show that carbonated soft drinks are in constant steady demand. More than $95 \%$ of the population regularly buy this product, including for children. About a third of the respondents pay attention to the composition of the product. At the same time, drinks made from natural herbal medicinal raw materials are bought by $76.5 \%$ of consumers.

When assessing quality by organoleptic indicators, it was found that drinks based on extracts from wildgrowing medicinal raw materials had a brown or tan color. According to the results of the tasting assessment, only a drink based on the licorice root extract having a gray-brown color turned out to be unattractive by "color". All drinks were characterized by the presence of opalescence or turbidity and sediment. The most turbid drinks were drinks based on linden flowers, licorice root, chicory and thyme herbs.

The taste and aroma of drinks were determined by the taste and aroma of the plant materials used. Drinks 
based on extracts from dry fruits of hawthorn, echinacea grass, linden flowers, lingonberry leaves, rose hips and thyme grass had the most harmonious and attractive taste. These options scored a greater number of points when calculating a comprehensive quality indicator for organoleptic indicators (Table 4).

Table 4. Summary results of organoleptic quality assessment for soft carbonated drinks

\begin{tabular}{|c|c|c|c|c|c|c|c|}
\hline \multirow[b]{2}{*}{$\begin{array}{c}\text { A variant } \\
\text { of the use } \\
\text { of medicinal } \\
\text { plant materials }\end{array}$} & \multicolumn{5}{|c|}{ Scoring } & \multirow[b]{2}{*}{ 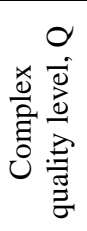 } & \multirow[b]{2}{*}{ 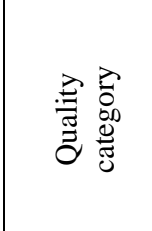 } \\
\hline & $\frac{\overline{0}}{0}$ & 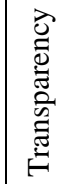 & $\frac{\dot{0}}{0}$ & $\begin{array}{l}\dot{\bar{\sigma}} \\
\stackrel{a}{I}\end{array}$ & 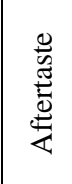 & & \\
\hline 1. Hawthorn & 4.57 & 4.28 & 4.57 & 4.71 & 4.42 & 90.9 & $\begin{array}{l}\text { excellent } \\
\text { quality }\end{array}$ \\
\hline 2. Lingonberry & 5.00 & 4.57 & 4.28 & 3.42 & 3.00 & 82.5 & $\begin{array}{c}\text { good } \\
\text { quality }\end{array}$ \\
\hline $\begin{array}{l}\text { 3. Linden } \\
\text { flowers }\end{array}$ & 4.71 & 3.85 & 4.57 & 4.28 & 4.14 & 85.7 & $\begin{array}{c}\text { good } \\
\text { quality }\end{array}$ \\
\hline 4. Coltsfoot & 4.57 & 4.28 & 3.85 & 3.00 & 3.14 & 73.4 & $\begin{array}{c}\text { good } \\
\text { quality }\end{array}$ \\
\hline 5. Licorice root & 3.71 & 3.71 & 3.28 & 2.28 & 2.48 & 58.1 & $\begin{array}{c}\text { unsatisfacto } \\
\text { ry quality }\end{array}$ \\
\hline 6. Chicory & 4.14 & 4.14 & 4.14 & 2.85 & 2.42 & 67.7 & $\begin{array}{c}\text { satisfactory } \\
\text { quality }\end{array}$ \\
\hline 7. Thyme herb & 4.57 & 4.14 & 4.71 & 3.57 & 3.57 & 80.3 & $\begin{array}{c}\text { good } \\
\text { quality }\end{array}$ \\
\hline 8.Salvia & 4.14 & 4.00 & 3.85 & 3.28 & 2.85 & 70.3 & $\begin{array}{c}\text { satisfactory } \\
\text { quality }\end{array}$ \\
\hline 9. Dogrose & 4.42 & 4.28 & 4.28 & 3.85 & 3.85 & 81.1 & $\begin{array}{l}\text { good } \\
\text { quality }\end{array}$ \\
\hline 10. Echinacea & 4.85 & 4.71 & 5.00 & 4.28 & 3.71 & 88.2 & $\begin{array}{l}\text { excellent } \\
\text { quality }\end{array}$ \\
\hline
\end{tabular}

Drinks containing chicory were characterized by low values of the complex quality indicator according to organoleptic indicators, and the drink containing licorice root had an unsatisfactory quality. The reason for this assessment was the presence of a specific bitter taste and an unpleasant aftertaste when drinking these drinks.

The mass fraction of solids was determined by the recipe calculated on the basis of extractivity of plant materials. It was 6.6-6.7 \% of which sugar accounted for $6 \%$, and $0.6-0.7 \%$ were extractable substances of medicinal plant materials.

The third group of products that are in constant steady demand is meat products, including sausages. Sausages produced are not the most favorable food for human health. In our opinion, this group of food products cannot be ignored.

Recipes for sausage products include a large number of spices and spicy vegetables. The inclusion of local wild medicinal plant materials should be considered as an additional ecosystem service, contributing to an increase in their functional significance.

In our experience, we studied the effect of wateralcohol infusions of wild medicinal herbs on the quality of poultry sausages.

Before the production of sausages using wateralcohol infusions of herbs, the level of active acidity (pH) was determined by the potentiometric method. A relatively small $\mathrm{pH}$ level -6.16 - was observed in the "control" variant of sausages. When water-alcohol infusion of herbs was added to the meat, a slight increase in the value was observed. When the water-alcohol infusion of magnolia vine is added to the minced system, the hydrogen index increases up to 6.22. With the addition of water-alcohol infusion of yarrow, the $\mathrm{pH}$ increases up to 6.25 units. The sausage has a hydrogen index of 6.26 units using a water-alcohol mixture from a turnip and a simple water-alcohol mixture. The highest $\mathrm{pH}$ level was observed in sausages whe using the wateralcohol infusion from wort -6.28 .

To study the effect of water-alcohol herbal infusions on the quality of sausages, organoleptic indicators were determined on a 9-point scale. The appearance of the samples is not very different from each other. All sausages scored 9 points. The color characteristics differed slightly. According to this indicator, preferences were given to all the options, except for sausages with wort and yarrow infusions ( 8 points). The best smell and aroma were observed in the options with narrow-leaved fireweed and agrimonia infusions (9 points). Options without the use of infusions and with a Hypericum perforatum infusion got 8 points. Sausage with a yarrow infusion were characterized by a weak spicy-bitter aroma, an unusual smell of meat products ( 7 points). The smallest number of points was given to sausages with a lemongrass infusion due to their unpleasant alcohol smell and an unusual lemon aroma (6 points).

The sausages had different tastes. Sausages with narrow-leaved fireweed and agrimonia which scored 9 points had the best taste. Sausages without additives and with wort got 7-8 points. For sausages with wateralcohol wort and lemongrass infusions, the score was sharply reduced for their after-taste (6 points).

When determining microbiological indicators, it was found that the greatest inhibitory effect on the development of bacteria is observed in the water-alcohol infusion made from narrow-leaved fireweed $(1.2 \cdot 10$ $\mathrm{CFU} / \mathrm{g})$ and the water-alcohol mixture $(1.4 \cdot 10, \mathrm{CFU} / \mathrm{g})$, and the smallest effect was observed in water-alcohol infusions made from yarrow $(3.6 \cdot 10, \mathrm{CFU} / \mathrm{g})$, agrinomia $(3.8 \cdot 10, \mathrm{CFU} / \mathrm{g})$ and lemongrass $(6.3 \cdot 10, \mathrm{CFU} / \mathrm{g})$.

One of the ways to give the product functional properties is to use thistle spotted as a part of sausage minced meat. This supplement contains a unique hepatoprotective substance - silymarin, which restores liver cells, stimulates the regeneration of all internal organs, and enriches the body with oxygen

The use of milk thistle meal in the amount of 1.0, 3.0, 6.0 and $9.0 \%$ per $100.0 \mathrm{~kg}$ of unsalted raw materials affected the consumer properties of cooked sausages. The sausages have a similar appearance.

The smell and severity of the aroma were different. 9 points were given to sausages produced without additives and with additives in the amount of up to $3.0 \%$ of the weight of unsalted raw materials.

The taste depended on the amount of meal in the minced meat. This indicator did not change when adding $3.0 \%$ of the additives ( 9 points). An increase in the amount of additives over $3.0 \%$ reduced the taste by $1-4$ points. 
The color of minced meat without milk thistle meal was pink, without gray spots, voids, evenly mixed with pultry pieces of $3 \ldots 5 \mathrm{~mm}$ in size. When the meal was added at the level of $1.0 \%$, there appeared dark inclusions on the surface. An increase in the proportion of phyto-enrichment over $3.0 \%$ worsened color and appearance.

The mass fraction of milk thistle meal in minced meat significantly affected the consistency of sausages. An increase in density of sausages was linear, reaching maximum values when adding meal to sausage meat in the amount of $9.0 \%$ of the weight of unsalted raw materials. At the same time, a negative correlation with an indicator of juiciness of finished products was observed.

The use of milk thistle meal increased protein content by $0.6-0.8 \%$ depending on the dose, and affected the fat content. It ranged from 18.1 to $20.6 \%$. At the same time, its greatest content was observed when adding 6.0 and $9.0 \%$ of the weight of minced meat. This pattern is explained by the presence of oil in e milk thistle meal which influenced the value of the indicator.

\section{Discussion}

Currently, the food market is quite diverse by its assortment and prices. If earlier consumers preferred attractive products, today, healthy properties are of greater importance. The trend of a "healthy" lifestyle opens up broad prospects. At the same time, this makes it possible to determine appropriate dietary strategies and solve the problem of prevention of chronic degenerative diseases.

The use of wild-growing medicinal raw materials provides products with functional properties. The use of these phytochemicals is promising in the production of food groups that are constantly in the diet of the population. Such foods are bread, soft drinks and sausages.

Studies have shown that introducing additional wildgrowing medicinal raw materials into the formulation has a positive effect on the dough maturation due to the high content of mono- and disaccharides, organic acids and minerals. This aspect is especially interesting because many bakeries often use a pressureless method for preparing dough to reduce the duration of the production cycle. At the same time, the duration of the fermentation process is significantly reduced, and accumulation of substances determines the taste of bread. Yeast activation will partially solve this problem. It seems interesting to carry out further comparative studies to identify the effect of phyto-enrichment agents on the quality of dough and bread when they are introduced at different stages (preparing the dough and kneading the dough), as well as on the intensity of the staling process.

When producing soft drinks, the type of plant materials determines the organoleptic and physiological value. During the tasting, the fact of a high rating of drinks (when conducting marketing research) was established. This indicates that buyers prefer soft drinks based on natural, safe raw materials.

Improving the consumer properties of food products through the use of wild plant materials is achieved at a low dosage. Given that the hardware and technological schemes for the production of food products using phyto-enrichment agents do not require changes, new types of products can be produced.

\section{Conclusion}

The use of wild-growing medicinal raw materials in the production of bread, soft drinks and sausages is a relevant and promising area, as the emphasis on the health aspect is one of the most powerful factors.

The introduction of phyto-enrichment agents has a positive effect on dough maturation processes due to the high content of mono- and disaccharides, organic acids and minerals.

When producing white flour bread using thyme powder, its optimal amount is $1 \%$, and using chicory flour $-3 \%$ of the weight of flour.

The use of wild medicinal raw materials is more justified in the form of water infusions because the absence of herb particles and fibers eliminates dark inclusions in the dough and helps preserve its rheological properties.

When producing non-alcoholic carbonated drinks using wild medicinal raw materials (fruits of hawthorn, echinacea, linden flowers, lingonberry leaves, rose hips and thyme), they have harmonious and attractive taste.

When producing sausages, wild-growing medicinal raw materials can be used in the form of water-alcohol infusions and crushed raw materials. When determining the microbiological indicators of the quality of sausages, it was found that the greatest inhibitory effect of the development of bacteria has a water-alcohol infusion of narrow-leaved fireweed.

The introduction of milk thistle meal into the sausage meat in the amount of up to $3.0 \%$ does not impair the organoleptic quality indicators of poultry sausages.

\section{References}

1. T. Ndlovu, F. Jaarsveld, O.J. Caleb, Food R. Int. $\begin{array}{llll}\text { 116, } 840-858 & \text { (2019) DOI }\end{array}$ 10.1016/j.foodres.2018.09.020

2. R.A. Xiaoling, X.Ju. Liu, Ch. Guan, Archives of Gerontology and Geriatrics 76, 125-132 (2018) DOI 10.1016/j.archger.2018.02.011

3. Yu. Sc. Edward, S. Vasanti, Sc. D. Malik, B. Frank, M.D. Hu, J. of the Amer. College of Cardiology 72, 914-926 (2018) DOI 10.1016/j.jacc.2018.02.085

4. K. Braha, A. Cupák, J. Pokrivčák, A. Qineti, M. Rizov, Economics \& Human Biology 27, 261274 (2017) DOI 10.1016/j.ehb.2017.08.003

5. K. Nowotny, D. Schröter, M. Schreiner, T. Grune, Ageing Res. Reviews 47, 55-66 (2018) DOI 10.1016/j.arr.2018.06.005 
6. Z.E. Martins, O. Pinho, V.O. Ferreira, Trends in Food Sci. \& Techn. 67, 106-128 (2017)

7. N. Krigas, D. Lazari, E. iMaloupa, M. Stikoudi, Int. J. of Gastronomy and Food Sci. 2(2), 112-118 (2015) DOI 10.1016/j.ijgfs.2015.02.001

8. A. Atala, Int. J. of Gastronomy and Food Sci. 1(1), 61-63 (2012) DOI 10.1016/j.ijgfs.2011.11.001

9. C.J.E. Schulp, W. Thuiller, P.H. Verburg, Ecological Economics 105, 292-305 (2014)

10. G. Menendez-Baceta, M. Pardo-de-Santayana, L. Aceituno-Mata, J. Tardío, V. Reyes-García, Appetite 112, 9-16 (2017) DOI 10.1016/j.appet.2017.01.010

11. P.M. Guarrera, V. Savo, J. of Ethnopharmacology 185, 202-234 (2016) DOI 10.1016/j.jep.2016.02.050
12. B. Guldiken, G. Ozkan, G. Catalkaya, F. Duygu, Ceylan, Food and Chemical Toxicology 119, 37-49 (2018) DOI 10.1016/j.fct.2018.05.050

13. S.A. Petropoulos, Â. Fernandes, N. Tzortzakis, M. Sokovic, A. Ciric, L. Barros, I.C.F.R. Ferreira, Food Res. Int.l 119, 859-868 (2019) DOI 10.1016/j.foodres.2018.10.069

14. M.M. Tajkarimi, S.A. Ibrahim, D.O. Cliver, Food Control 21, 1199-1218 (2010) DOI 10.1016/j.foodcont.2010.02.003

15. J. García-Díez, J. Alheiro, A.L. Pinto, L. Soares, V. Falco, M.J. Fraqueza, L. Patarata, Food Control 59, 262-270 (2016) DOI 10.1016/j.foodcont.2015.05.027 